Terbit online pada laman web jurnal : http://e-journal.sastra-unes.com/index.php/JIPS

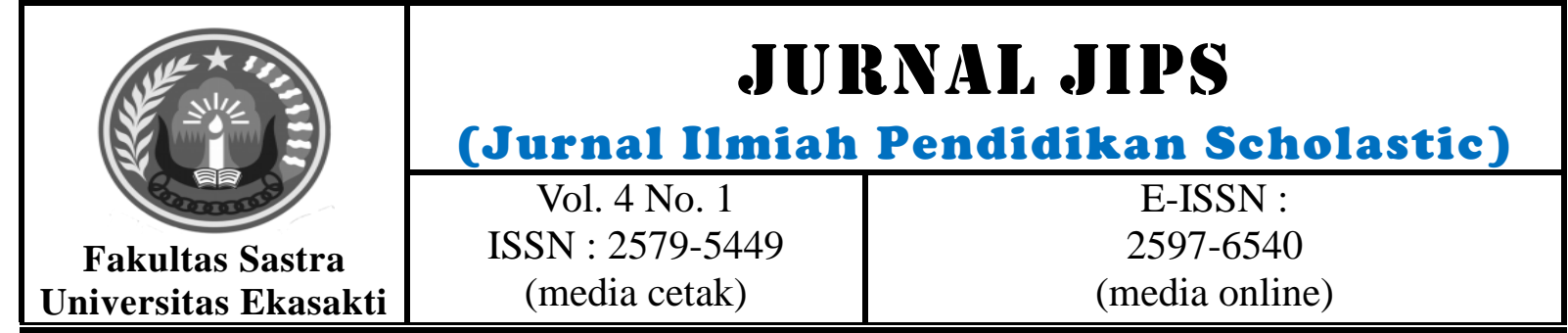

\title{
UPAYA MENINGKATKAN MINAT BELAJAR SISWA PADA PENJUMLAHAN DAN PENGURANGAN DENGAN METODE JARIMATIKA DI SD NEGERI O10 PAGARAN TAPAH DARUSSALAM
}

\author{
Sugiyarti \\ SD Negeri 010 Pagaran Tapah
}

\begin{abstract}
This research is motivated by the low of student interest in learning mathematics. This study aims to describe the application of Jarimatika to increase student interest in the addition and reduction of numbers to 20 students in grade I of SD Negeri 010 Pagaran Tapah Darussalam. The subjects of this study were 8 students in the academic year 2019-2020. The form of research is classroom action research. Data collection techniques used were observation techniques and initial reading ability tests. Based on the results of the study, it can be concluded that the students 'learning interest in the preliminary data before the action, the students' learning interest is obtained by an average of $47.22 \%$ with a low category. Then based on observations in the first cycle of the first meeting which shows that the level of student learning interest reaches an average percentage of $56.49 \%$ with a high category and at the second meeting reaches an average percentage of $66.67 \%$. Whereas in the second cycle the first meeting there was an increase in achieving student learning interest obtained an average percentage of $84.72 \%$ with a high category and at the second meeting increased to $91.67 \%$.
\end{abstract}

Keywords: Student Interest in Learning, Jarimatika Method

(C) 2020 Jurnal JIPS

Abstrak

Penelitian ini dilatarbelakangi oleh rendahnya minat belajar siswa dalam pelajaran matematika. Penelitian ini bertujuan untuk mendeskripsikan penerapan jarimatika dalam upaya meningkatkan minat belajar siswa pada materi pejumlahan dan pengurangan bilangan sampai 20 siswa kelas I SD Negeri 010 Pagaran Tapah Darussalam. Subjek penelitian ini adalah 8 orang siswa tahun pelajaran 2019-2020. Bentuk penelitian adalah penelitian tindakan kelas. Teknik pengumpulan data yang digunakan adalah teknik observasi dan tes kemampuan membaca permulaan.Berdasarkan hasil penelitian, dapat disimpulkan bahwa minat belajar siswa pada data awal sebelum tindakan, minat belajar siswa diperoleh rata-rata persentase $47.22 \%$ dengan kategori rendah. Kemudian berdasarkan hasil observasi pada siklus pertama pertemuan pertama yang menunjukkan bahwa tingkat minat belajar siswa mencapai dengan rata-rata persentase 56,49\% dengan kategori tinggi dan pada pertemuan kedua mencapai rata-rata persentase $66.67 \%$. Sedangkan pada siklus II pertemuan pertama terjadi peningkatan mencapai minat belajar siswa diperoleh rata-rata persentase 84,72\% dengan kategori tinggi dan pada pertemuan kedua meningkat menjadi 91,67\%.

Keywords: Minat Belajar Siswa, Metode Jarimatika

Jurnal JIPS (Jurnal Ilmiah Pendidikan Scholastic ) Vol. 4 No. 1 (2020) ISSN : 2579-5449

This work is licensed under a Creative Commons Attribution-NonCommercial 4.0 International License. 


\section{INTRODUCTION}

Matematika merupakan salah satu ilmu dasar yang mempunyai peranan penting dalam dunia pendidikan, karena pelajaran matematika merupakan sarana yang dapat digunakan untuk membentuk siswa berpikir secara ilmiah. Sebagaimana tercantum dalam Kurikulum Tingkat Satuan Pendidikan , tujuan pembelajaran matematika adalah sebagai berikut: (1) memahami konsep matematika, menjelaskan keterkaitan antar konsep dan mengaplikasikan konsep atau algoritma secara luwes, akurat, efisien, dan tepat dalam pemecahan masalah; (2) menggunakan penalaran pada pola dan sifat, melakukan manipulasi matematika dalam membuat generalisasi, menyusun bukti, atau menjelaskan gagasan dan pernyataan matematika; (3) memecahkan masalah yang meliputi kemampuan memahami masalah, merancang model matematika, menyelesaikan model dan menafsirkan solusi yang diperoleh; (4) mengkomunikasikan gagasan dengan simbol, tabel, diagram, atau media lain untuk memperjelas keadaan atau masalah; dan (5) memiliki sikap menghargai kegunaan matematika dalam kehidupan, yaitu memiliki rasa ingin tahu, perhatian, dan minat dalam mempelajari matematika, serta sikap ulet dan percaya diri dalam pemecahan masalah (BNSP, 2006:2).

Untuk mencapai tujuan tersebut, tugas dan peranan guru sebagai pendidik profesional sesungguhnya sangat kompleks, tidak terbatas pada saat berlangsungnya interaksi edukatif di dalam kelas, yang lazim disebut proses belajar mengajar. Guru juga bertugas sebagai administrator, evaluator, konselor, dan lain-lain sesuai dengan sepuluh kompetensi (kemampuan) yang dimilikinya. Namun sebagai inti dari kegiatan pendidikan sekolah, proses belajar mengajar sangat menentukan hasil belajar yang akan dicapai oleh siswa.

Upaya yang telah dilakukan oleh guru di SD Negeri 010 Pagaran Tapah Darussalam sudah dilakukan dengan berbagai cara. Namun minat belajar masih juga kurang maksimal, hal tersebut mungkin karena metode ceramah yang digunakan kurang menarik minat siswa sehingga siswa kurang termotivasi untuk mengikuti pembelajaran yang disampaikan oleh guru.

Berdasarkan hasil pengamatan selama peneliti bertugas di SD Negeri 010 Pagaran Tapah Darussalam menemukan fakta bahwa pembelajaran berhitung penjumlahan dan pengurangan bilangan sampai 20 di sekolah tersebut masih memunculkan permasalahan yang harus dicarikan solusinya, yaitu sebagian besar siswa kemampuannya dalam melakukan penjumlahan dan pengurangan bilangan sampai 20 masih rendah. Hal tersebut ditunjukkan dengan hasil belajar siswa yang belum mencapai kriteria ketuntasan minimal (KKM). Adapun KKM di kelas I SD Negeri 010 Pagaran Tapah Darussalam untuk pelajaran matematika sebesar 70.

Salah satu solusi untuk mengatasi rendahnya kemampuan berhitung siswa tersebut adalah mengganti media dadu dengan media yang dapat mengatasi kesalahan-kesalahan yang telah dilakukan oleh siswa dalam berhitung. Jarimatika merupakan salah satu media berhitung yang menggunakan jari siswa sebagai media berhitungya. Jarimatika sebagai media berhitung mempunyai beberapa kelebihan, yaitu siswa dapat melakukan penjumlahan dan pengurangan dengan cepat dengan langkah yang sederhana, siswa tinggal membuka sejumlah jarinya untuk melakukan penjumlahan dan menutup sejumlah jarinya untuk melakukan pengurangan. Selain itu, dengan jarimatika penjumlahan dan pengurangan dengan angka besar maupun kecil, prosesnya tetap sama-sama sederhana dan cepat, dikarenakan perbedaan besar dan kecilnya sebuah bilangan hanya terletak pada perbedaan formasi jari siswa. Kelebihan yang lain dari jarimatika adalah medianya selalu terbawa kemana saja dan kapan saja, dikarenakan medianya adalah jari siswa sendiri.

Berdasarkan penjelasan di atas, peneliti tertarik untuk melakukan sebuah penelitian dengan judul "Upaya Meningkatkan Minat Belajar Siswa pada Pejumlahan dan Pengurangan dengan Metode Jarimatika di SD Negeri 010 Pagaran Tapah Darussalam". 


\section{RESEARCH METHODS}

Penelitian tindakan kelas ini dilaksanakan di SD Negeri 010 Pagaran Tapah Darussalam. Mata pelajaran yang diteliti adalah mata pelajaran Matematika. Penelitian ini dilakukan dalam dua siklus dan tiap siklus dilakukan dalam dua kali pertemuan. Sebagai subjek dalam penelitian ini adalah siswa kelas I SD Negeri 010 Pagaran Tapah Darussalam dengan jumlah siswa sebanyak 8 orang. Penelitian ini dilakukan dalam dua siklus dan tiap siklus dilakukan dalam dua kali pertemuan. Penelitian ini mengacu pada Standar Kompetensi, Kompetensi Dasar dan indikator pembelajaran Matematika pada kelas I, maka proses implementasi mengenai seluruh indikator tersebut dapat dibagi menjadi $2 \mathrm{x}$ pertemuan pembelajaran.

Agar penelitian tindakan kelas ini berhasil dengan baik tanpa hambatan yang mengganggu kelancaran penelitian, peneliti menyusun tahapan-tahapan yang dilalui dalam penelitian tindakan kelas, yaitu perencanaan/persiapan tindakan, pelaksanaan tindakan, observasi, dan Refleksi.

Data dalam penelitian ini dikumpulkan dengan cara teknik observasi dan dokumentasi. Setelah data terkumpul melalui observasi, data tersebut diolah dengan menggunakan rumus persentase (Anas Sudijono, 2004:43), yaitu sebagai berikut:

$$
\mathrm{P}=\frac{\mathrm{F}}{\mathrm{N}} x 100 \%
$$

Keterangan:

$\mathrm{F}$ = Frekuensi yang sedang dicari persentasenya

$\mathrm{N}=$ Number of Cases (jumlah frekuensi/banyaknya individu)

$\mathrm{P}=$ Angka persentase

100\% = Bilangan Tetap

- Hasil perhitungan data dalam bentuk persentase dikelompokkan ke dalam 4 kriteria penilaian baik, cukup, kurang baik dan tidak baik, untuk lebih jelasnya sebagai berikut $76 \%$ sampai $100 \%$ tergolong sangat tinggi, 56\% sampai $75 \%$ tergolong tinggi, $40 \%$ sampai $55 \%$ tergolong sedang dan $40 \%$ kebawah tergolong rendah. Siswa yang dianggap tuntas belajar, bila telah mencapai 56\% - $75 \%$ dengan kategori tergolong tinggi.

\section{RESULTS AND DISCUSSION}

Berdasarkan dari hasil analisis terhadap minat belajar siswa Pada Mata Pelajaran Matematika Kelas I SD Negeri 010 Pagaran Tapah Darussalam sebelum dilakukannya tindakan, diketahui bahwa minat belajar siswa dalam pelajaran matematika tergolong rendah dengan jumlah rata-rata persentase sebesar $47.22 \%$. Untuk mengetahui lebih detail mengenai belajar siswa sebelum tindakan dapat dilihat pada tabel berikut:

Tabel 1.Minat Belajar Siswa Sebelum Tindakan

\begin{tabular}{|c|l|c|c|}
\hline No & \multicolumn{1}{|c|}{ Aktivitas } & Skor & Persentase \\
\hline 1 & $\begin{array}{l}\text { Siswa } \\
\text { memperhatikan } \\
\text { dengan serius } \\
\text { penjelasan guru }\end{array}$ & 7 & 58.33 \\
\hline 2 & Siswa & 5 & 41.67 \\
\hline
\end{tabular}

\begin{tabular}{|c|l|c|c|} 
& $\begin{array}{l}\text { mengemukakan } \\
\text { pendapat sesuai } \\
\text { materi pelajaran }\end{array}$ & & \\
\hline 3 & $\begin{array}{l}\text { Siswa tekun } \\
\text { dalam belajar }\end{array}$ & 6 & 50.00 \\
\hline 4 & $\begin{array}{l}\text { Siswa } \\
\text { menanyakan } \\
\text { tentang kesulitan } \\
\text { dalam belajar }\end{array}$ & 4 & 33.33 \\
\hline 5 & $\begin{array}{l}\text { Siswa belajar } \\
\text { dengan riang }\end{array}$ & 5 & 41.67 \\
\hline 6 & $\begin{array}{l}\text { Siswa tidak takut } \\
\text { bertanya pada } \\
\text { guru }\end{array}$ & 7 & 58.33 \\
\hline \multicolumn{2}{|c|}{ Jumlah } & 34 & \\
\hline \multicolumn{2}{|c|}{ Rata-rata } & 47.22 \\
\hline
\end{tabular}

Jurnal JIPS (Jurnal Ilmiah Pendidikan Scholastic ) Vol. 4 No. 1 (2020) ISSN : 2579-5449

This work is licensed under a Creative Commons Attribution-NonCommercial 4.0 International License. 
Berdasarkan tabel IV. 1 di atas, dapat dijelaskan bahwa minat belajar siswa sebelum diterapkan metode jarimatika dalam pelajaran matematika siswa secara klasikal masih tergolong kurang baik dengan perolehan rata-rata persentase $47.22 \%$.

Dalam penelitian ini tindakan dilakukan dalam 2 siklus yaitu siklus I dan siklus II yang masing-masing siklus terdiri dari dua pertemuan. Setelah dilakukan tindakan dengan menggunakan metode jarimatika, maka hasil belajar dari siklus I dapat dilihat pada tabel berikut.

Tabel 2. Hasil Observasi Minat Belajar Siswa Siklus 1 Pertemuan 1

\begin{tabular}{|c|c|c|c|}
\hline No & Aktivitas & Skor & Persentase \\
\hline 1 & $\begin{array}{l}\text { Siswa } \\
\text { memperhatikan } \\
\text { dengan serius } \\
\text { penjelasan guru }\end{array}$ & 7 & 58.33 \\
\hline 2 & $\begin{array}{l}\text { Siswa } \\
\text { mengemukakan } \\
\text { pendapat sesuai } \\
\text { materi } \\
\text { pelajaran }\end{array}$ & 7 & 58.33 \\
\hline 3 & $\begin{array}{l}\text { Siswa tekun } \\
\text { dalam belajar }\end{array}$ & 6 & 50.0 \\
\hline 4 & $\begin{array}{l}\text { Siswa } \\
\text { menanyakan } \\
\text { tentang } \\
\text { kesulitan dalam } \\
\text { belajar }\end{array}$ & 5 & 41.67 \\
\hline 5 & $\begin{array}{l}\text { Siswa belajar } \\
\text { dengan riang }\end{array}$ & 6 & 50.0 \\
\hline 6 & $\begin{array}{l}\text { Siswa tidak } \\
\text { takut bertanya } \\
\text { pada guru }\end{array}$ & 6 & 50.0 \\
\hline \multicolumn{2}{|r|}{ Jumlah } & 34 & \\
\hline & Rata-rata & & 51.39 \\
\hline
\end{tabular}

Tabel 3. Hasil Observasi Minat Belajar Siswa Siklus 1 Pertemuan 2

\begin{tabular}{|c|c|c|c|}
\hline No & Aktivitas & Skor & Persentase \\
\hline 1 & $\begin{array}{l}\text { Siswa } \\
\text { memperhatikan } \\
\text { dengan serius } \\
\text { penjelasan guru }\end{array}$ & 7 & 58.33 \\
\hline 2 & $\begin{array}{l}\text { Siswa } \\
\text { mengemukakan } \\
\text { pendapat sesuai } \\
\text { materi }\end{array}$ & 7 & 58.33 \\
\hline
\end{tabular}

\begin{tabular}{|c|l|c|c|} 
& pelajaran & & \\
\hline 3 & $\begin{array}{l}\text { Siswa tekun } \\
\text { dalam belajar }\end{array}$ & 6 & 50.0 \\
\hline & $\begin{array}{l}\text { Siswa } \\
\text { menanyakan } \\
\text { tentang } \\
\text { kesulitan dalam } \\
\text { belajar }\end{array}$ & 6 & 50.0 \\
\hline 5 & $\begin{array}{l}\text { Siswa belajar } \\
\text { dengan riang }\end{array}$ & 7 & 58.33 \\
\hline 6 & $\begin{array}{l}\text { Siswa tidak } \\
\text { takut bertanya } \\
\text { pada guru }\end{array}$ & 6 & 50.0 \\
\hline \multicolumn{2}{|l|}{ Jumlah } & 39 & 66.67 \\
\hline \multicolumn{2}{|l}{ Rata-rata } & &
\end{tabular}

Berdasarkan tabel 2 dan 3, dapat dijelaskan bahwa minat belajar siswa pada siklus I Pertemuan I secara klasikal tergolong rendah dengan perolehan rata-rata persentase $51.39 \%$. Sedangkan hasil observasi minat belajar siswa pada siklus I pertemuan 2 mengalami peningkatan persentase menjadi $66.67 \%$. dengan demikian hasil observasi pada siklus pertama belum memenuhi indikator keberhasilan penelitian tindakan kelas dan dilanjutkan dengan penelitian tindakan kelas siklus II.

Dari hasil pelaksanaan tindakan pada siklus I, maka segera dilakukan refleksi untuk menganalisis ketercapaian tindakan yang telah dilakukan. Sebagaimana hasil observasi yang telah diuraiankan di atas, dapat diketahui bahwasanya dalam pembelajaran aktivitas guru, aktivitas siswa masih banyak kelemahan. Oleh sebab itu adapun upaya yang akan peneliti lakukan lebih sering mengenalkan lambinglambang penjumlahan yang digunakan dalam jarimatika dan akan lebih sering memberikan kesempatan pada siswa untuk bertanya jika ada materi yang belum dimengerti, lebih memaksimalkan dalam menerapkan langkahlangkah pembelajaran, dan akan mengawasi siswa dalam pembelajaran dan meningkatkan aktivitas guru dan aktivitas siswa.

Jurnal JIPS (Jurnal Ilmiah Pendidikan Scholastic ) Vol. 4 No. 1 (2020) ISSN : 2579-5449

This work is licensed under a Creative Commons Attribution-NonCommercial 4.0 International License. 
Tabel 4. Hasil Observasi Minat Belajar Siswa Siklus II Pertemuan 1

\begin{tabular}{|c|c|c|c|}
\hline No & Aktivitas & Skor & Persentase \\
\hline 1 & $\begin{array}{l}\text { Siswa } \\
\text { memperhatikan } \\
\text { dengan serius } \\
\text { penjelasan guru }\end{array}$ & 9 & 75.0 \\
\hline 2 & $\begin{array}{l}\text { Siswa } \\
\text { mengemukakan } \\
\text { pendapat sesuai } \\
\text { materi } \\
\text { pelajaran }\end{array}$ & 9 & 75.0 \\
\hline 3 & $\begin{array}{l}\text { Siswa tekun } \\
\text { dalam belajar }\end{array}$ & 8 & 66.67 \\
\hline 4 & $\begin{array}{l}\text { Siswa } \\
\text { menanyakan } \\
\text { tentang } \\
\text { kesulitan dalam } \\
\text { belajar }\end{array}$ & 10 & 83.33 \\
\hline 5 & $\begin{array}{l}\text { Siswa belajar } \\
\text { dengan riang }\end{array}$ & 9 & 75.0 \\
\hline 6 & $\begin{array}{l}\text { Siswa tidak } \\
\text { takut bertanya } \\
\text { pada guru }\end{array}$ & 8 & 66.67 \\
\hline \multicolumn{2}{|r|}{ Jumlah } & 53 & \\
\hline & Rata-rata & & 73.61 \\
\hline
\end{tabular}

Tabel 5. Hasil Observasi Minat Belajar Siswa Siklus II Pertemuan 2

\begin{tabular}{|c|c|c|c|}
\hline No & \multicolumn{1}{|c|}{ Aktivitas } & Skor & Persentase \\
\hline 1 & $\begin{array}{l}\text { Siswa } \\
\text { memperhatikan } \\
\text { dengan serius } \\
\text { penjelasan guru }\end{array}$ & 11 & 91.67 \\
\hline 2 & $\begin{array}{l}\text { Siswa } \\
\text { mengemukakan } \\
\text { pendapat sesuai } \\
\text { materi } \\
\text { pelajaran }\end{array}$ & 10 & 83.33 \\
\hline 3 & $\begin{array}{l}\text { Siswa tekun } \\
\text { dalam belajar }\end{array}$ & 10 & 83.33 \\
\hline 4 & $\begin{array}{l}\text { Siswa } \\
\text { menanyakan } \\
\text { tentang } \\
\text { kesulitan dalam } \\
\text { belajar }\end{array}$ & 11 & 91.67 \\
\hline 5 & $\begin{array}{l}\text { Siswa belajar } \\
\text { dengan riang }\end{array}$ & 11 & 91.67 \\
\hline 6 & $\begin{array}{l}\text { Siswa tidak } \\
\text { takut bertanya } \\
\text { pada guru }\end{array}$ & 10 & 83.33 \\
\hline
\end{tabular}

\begin{tabular}{|c|c|c|}
\hline Jumlah & 66 & \\
\hline Rata-rata & & 87.50 \\
\hline
\end{tabular}

Berdasarkan tabel 4 dan 5, dapat dijelaskan bahwa minat belajar siswa pada siklus II Pertemuan I secara klasikal tergolong tinggi dengan perolehan rata-rata persentase $73.61 \%$. Sedangkan hasil observasi minat belajar siswa pada siklus II pertemuan II mengalami pengkatan persentase sebesar $87.50 \%$.

Berdasarkan dari data perolehan nilai observasi terhadap minat belajar siswa melalui penerapan metode jarimatika dalam pelajaran Matematika pada materi penjumlahan dan pengurangan bilangan sampai dengan 20 kelas I SD Negeri 010 Pagaran Tapah Darussalam secara individu mencapai target yang telah diharapkan yaitu mencapai KKM yang telah ditetapkan di sekolah yaitu 70. Aktivitas guru juga mengalami peningkatan, dari 6 aspek aktivitas siswa dapat terlaksana dengan baik, dalam arti aktivitas siswa telah terlaksana dengan baik atau sempurna.

Jika diperhatikan hasil siklus kedua, minat belajar yang ditunjukkan oleh siswa mengalami peningkatan dibanding dengan siklus pertama. Artinya tindakan yang diber;kan guru pada siklus kedua berdampak lebih baik dari tindakan pada siklus pertama. Hal ini memberikan gambaran bahwa untuk bisa membartu siswa melatih memecahkan sendiri masalah dalam belajar, siswa membutuhkan waktu untuk memahami materi tersebut. Pada awalnya siswa perlu dibimbing secara intensif, namun secara berangsur-angsur siswa diberi kesempatan untuk bisa menemukannya tanpa bantuan guru.

Pembatasan waktu yang diberikan untuk berdiskusi yang diajukan guru kepada siswa berdampak pula kepada basil yang baik. Siswa tidak membuangbuang waktu hingga, dua kali perternuan untuk menyelesaikan suatu permasalahan belajar. bimbingan khusus yang ditujukan kepada sebagian kecil siswa juga menunjukkan hasil yang baik. Ini terlihat dari minat belajar siswa pada siklus II pertemuan pertama mencapai rata-rata persentase 73.61, berada pada kategori tinggi dan pada pertemuan kedua meningkat dengan perolehan rata-rata persentase sebesar 87.50 , berada pada kategori sangat tinggi. Dari hasil ini menunjukkan bahwa kelemahan-kelemahan proses pembelajaran pada siklus I dapat diatasi pada siklus II.

Jurnal JIPS (Jurnal Ilmiah Pendidikan Scholastic ) Vol. 4 No. 1 (2020) ISSN : 2579-5449

This work is licensed under a Creative Commons Attribution-NonCommercial 4.0 International License. 


\section{CONCLUSION}

Berdasarkan hasil pembahasan dan analisis seperti dapat disimpulkan bahwa melalui metode jarimatika dapat meningkatkan minat belajar matematika siswa kelas I SD Negeri 010 Pagaran Tapah Darussalam.

Berdasarkan hasil observasi sebelum penerapan metode jarimatika minat belajar siswa pada data awal sebelum tindakan, minat belajar siswa diperoleh rata-rata persentase $47.22 \%$ dengan kategori rendah. Kemudian berdasarkan hasil observasi pada siklus pertama pertemuan pertama yang menunjukkan bahwa tingkat minat belajar siswa mencapai dengan rata-rata persentase $51.39 \%$ dengan kategori tinggi dan pada pertemuan kedua mencapai rata-rata persentase $66.67 \%$. Sedangkan pada siklus II pertemuan pertama terjadi peningkatan mencapai minat belajar siswa diperoleh rata-rata persentase $73.61 \%$ dengan kategori tinggi dan pada pertemuan kedua meningkat menjadi $87.50 \%$.

Keberhasilan ini dapat tercapai dipengaruhi oleh pengunaan metode jarimatika, aktivitas siswa menjadi lebih aktif yang berarti siswa cenderung positif dalam mengikuti proses pembelajaran yang diberikan oleh guru. Dengan demikian maka tingkat penerimaan siswa akan meningkat dan pada gilirannya dapat meningkatkan minat belajar siswa. 


\section{Bibliography}

[1]Dimyati dan Mudjiono. 2004. Belajar dan Pembelajaran. Jakarta: Rineka Cipta

[2]Dwi Sunar Prasetyono, 2008. Pintar Jarimatika, Yogyakarta: Diva Press

[3]Hendra BC dan A. Nur Widiastuti. 2009. Jari hitung cepat $A B C$ : berhitung cepat \& berhitung jari metode JHC-hand-sis berhitung cepat \& berhitung jari metode JHC-hand-sis. Jakarta: Elex Media Komputindo

[4]Mulyasa, E. 2007. Menjadi Guru Profesional Menciptakan Pembelajaran Kreatif dan Menyenangkan, Bandung: Rosda

[5]Sardiman. 2004. Interaksi dan Motivasi Belajar Mengajar. Jakarta: Rajawali Pers

[6]Septi Peni Wulandari, 2008. Jarimatika, Jakarta: Kawan Pustaka

[7]___ 2011. Jarimatika penambahan dan pengurangan, Jakarta Selatan: PT. Kawan Pustaka
$[8]$ Berhitung mudah dan menyenangkan dengan menggunakan jariBuku panduan untuk putra-putri Anda usia 3 - 10 tahun, diakses pada tanggal 25 April 2012--

[9]Slameto, 2003. Belajar dan Faktor-faktor yang Mempengaruhinya. Jakarta: Rineka Cipta

[10]__ 2006. Penelitian Tindakan Kelas. Jakarta: Bumi Aksara.

[11]Suryosubroto, 2002. Proses Belajar Mengajar di Sekolah, Jakarta: Rineka Cipta

[12]Syaodih Ibrahim, 2003. Perencanaan Pengajaran, Jakarta: Rineka Cipta, 2003

[13]Tulus Tu'u, Peran Disiplin pada Perilaku dan Prestasi Siswa, Jakarta:PT.Gransindo, 2004

[14]Winataputra S. Udin, 2001.Strategi Belajar Mengajar, Jakarta: Universitas Terbuka 